\title{
CONCEPTUAL MODELS OF THE QUALITY CONTROL PROCESS
}

\author{
A. RIBIKAUSKAS, O. VASILECAS, A. ČAPLINSKAS \\ Vilnius Gediminas Technical University \\ Sauletekio 11, LT-2040, Vilnius, Lithuania \\ E-mail: arunas@fm.vtu.lt
}

Received September 17, 1999; revised November 3, 1999

\begin{abstract}
This paper discusses issues of conceptual modelling of the product quality control process. Special attention is paid to the quality inspection. This process can be considered as a kind of product sorting the aim of which is to identify the product quality category. It is supposed that the sorting can be done according to prescriptive norms and standards. The paper considers the specific features of knowledge described by those norms and standards, discusses how to represent this knowledge by a logic program, and proposes a knowledge-based architecture of the software system that acts as a part of the quality system and implements the product quality inspection process.
\end{abstract}

\section{INTRODUCTION}

More and more people use computer systems at present. They desire their systems to be intelligent and simply to operate. In order to meet those requirements, computer systems need to know how to act reasonably. They must provide knowledge representation and reasoning capabilities. In other words, they must be knowledge-based systems.

Usually, a universal knowledge-based system is inefficient because patterns of knowledge used in different application domains (business, medicine, engineering, etc.) differ. An efficient system can be developed taking into account the specific features of domain knowledge only. Hence, the architecture of the system should follow from the knowledge pattern used and problems solved.

These paper aims at develop a conceptual architecture of a knowledge-based software system which intends to implement the product quality inspection process. In order to solve this problem, the paper discusses issues of conceptual modelling of the product quality control process, considers the specific 
features of knowledge described by quality inspection norms and standards, discusses how to represent this knowledge, and sets out system requirements and, finally, proposes an architecture that satisfies those requirements in the best way. The main conclusion is that a relational model and a logic program should model application and problem domains at the conceptual level respectively.

\section{THE NOTION OF QUALITY}

There is no comprehensive definition of quality. The definitions that exist can be divided in to two main groups [3].

According to the first point of view, the quality is a measure of excellence in a comparative sense. The word "quality" originated from Latin "qualitas" that means a characteristic that something has or has not. The quality is not absolute. We can present quality as an axis and improve it infinitely. Everything can be better as it is. The quality can be defined as "the constant achievement of all that your customer requires or expects" [8].

According to the second point of view, the supplier and buyer agree upon the quality. It is a subject to constrain [1]. The ISO 8402 standard [6] defines quality as a "totality of characteristics of an entity that bear on its ability to satisfy stated and implied needs". The standard supposes that there is a "correct" quality level. Hence, it defines quality as the degree to which a product or service meets or exceeds the needs of customers ("compliance with specifications") at a cost that represents a value to them. The quality that is better or worse than agreed-upon is not optimal.

Which point of view is applied depends on aims. The idea of exceeding customers' needs, for example, is based on the first point of view, the quality management practices - on the second one. In this paper, we follow the second point of view.

\section{CONCEPTUAL MODEL OF THE QUALITY SYSTEM}

A quality system is a network of control mechanisms and techniques that reduce the possibility of defects, deviation of design requirements or contractual terms. ISO 8402 [6] defines the quality system as "organizational structure, procedures, processes, and resources needed to implement quality management".

Quality systems are mostly based on a family of international standards ISO 9000. Standards define the minimal requirements for a quality system. The conceptual model of the ISO 9000-based quality system and its relation with quality management is presented in fig. 1. Let us discuss this model more in detail.

Quality manuals. Quality system documentation should create a formal environment in which everyone understands the why, what, where, when, by whom and how of the processes and activities involved [10]. It aims at: 


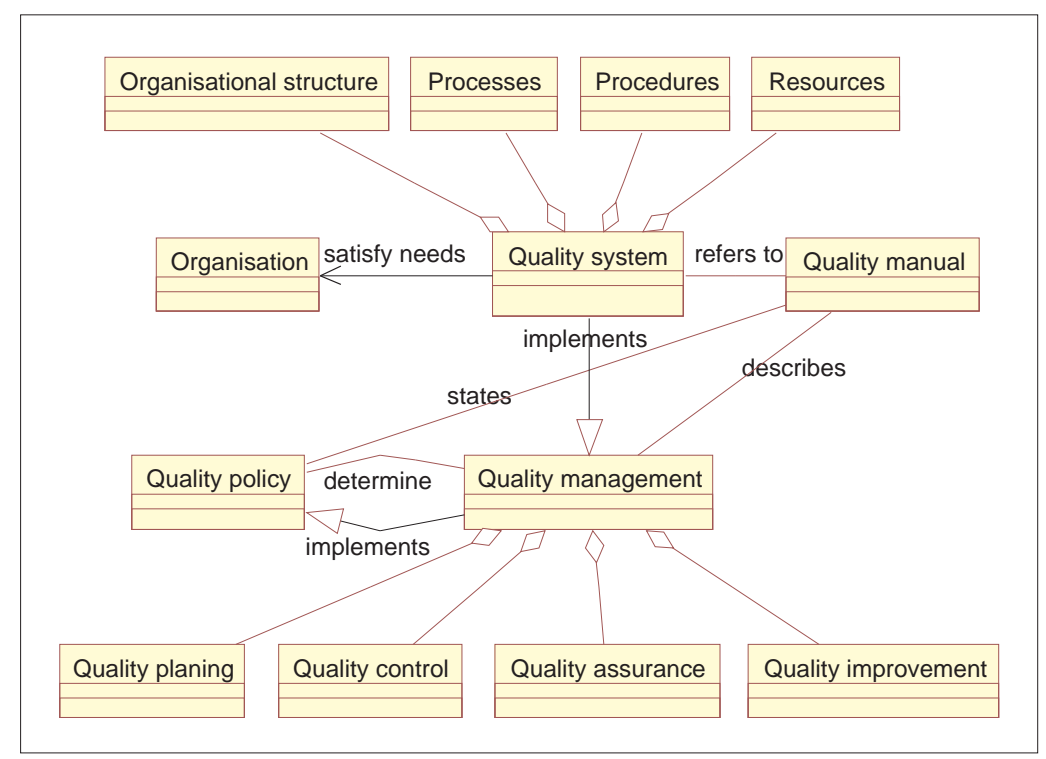

Figure 1. Conceptual model of the quality system.

- describing how the organization operates within the scope of the quality system,

- demonstrating customers and employees that the organization is committed to quality achievement and has the quality system which will enable it to succeed,

- encouraging consistency of action and uniformity of understanding throughout the organization,

- communicating instructions, information and also proposed and agreed changes to the quality system,

- opportunity for new members of the organization to sooner become productive and effective,

- ensuring the effective and continuous functioning of the organization even in absence of the key personnel,

- making auditing possible of the quality system to verify its effectiveness.

The most important documents are quality manuals. A quality manual is "a document stating the quality policy and describing the quality system of an organization" [6].

Processes, procedures, and resources. Normally, organization is divided into functions. However, products and services are not produced by functions but by a set of interrelated processes. Effectively performed processes require resources i.e., several individuals or groups from different functions have to work together in a planned and organized manner. Control of 
these processes is normally achieved by documented procedures that define the sequence of activities involved and the interfaces between these individuals or groups. Procedures are documents that describe "the rules of the game". Procedure is "a document defining the purpose and scope of a process and outlining what, where, when, and by whom the process shall be carried out". Where necessary, procedures may refer to more detailed work instructions specifying how individuals undertake one or more specific tasks. In the context of this paper special attention should be paid to quality inspection procedures.

Quality management. Quality management encompasses all companywide, integrated efforts aimed at improving the quality at every level. On the one hand, quality management determines and implements the quality policy. On the other hand, quality management is implemented itself by quality planning, quality control, quality assurance, and quality improvement using organizational structure, processes, procedures, and resources provided by the quality system.

\section{QUALITY CONTROL AND QUALITY INSPECTION}

Quality control is "the overall system of technical activities that measures the attributes and performance of a process, item or service against defined standards to verify that they meet the stated requirements established by the customer" [2]. It is a sequence of steps taken to make sure that a company's products or services are of sufficiently high quality [5], [6]. The emphasis is on technical activities. According to MIL-STD-188 series of standards quality control is defined as "a management function whereby control of the quality of raw materials, assemblies, produced material and components, services related to production, and management, production" 1

One of the most important technical activities in quality control is quality inspection. Despite the recent progress incorporating quality into manufacturing processes, quality inspection and diagnosis of defect causes remain important components of most quality systems (fig. 2.). Quality inspection aims at detecting defects caused by defective materials or the rendering of faulty manufacturing processes. Hence, only inspection allows estimating of the final quality of the product prior to supplying this product to the user. On the other hand, the quality inspection does not cover diagnosis of defect causes. The necessity to understand the relationship between cause and effect within a process is critical for improving the capability of a manufacturing process, and the resultant outputs. The quality control methods, which rely only on testing, inspection and sorting outputs and do not focus on establishing the cause of unacceptable outcomes, are outdated. It means that quality inspection must be viewed today as part of the diagnostic process.

Since the cost of defects escalates as a product is moving through the man-

\footnotetext{
${ }^{1}$ http://glossary.its.bldrdoc.gov/fs-1037/dir-029/_4292.htm
} 
ufacturing chain, quality inspection must be treated as part of a continuous quality improvement program. It means, that quality inspection should encompass incoming materials and intermediate products as well as the final product.

The quality inspection may be viewed as an output sorting problem, because it seeks to determine the category of product quality ${ }^{2}$ Usually inspection is performed as the inspection of a sample and of a lot to determine the category of the lot. There are two types of inspection: attribute sampling and variable sampling. In attribute sampling, the presence or absence of a characteristic is noted in each of the units inspected. In variables sampling, the numerical magnitude of a characteristic is measured and recorded for each inspected unit.

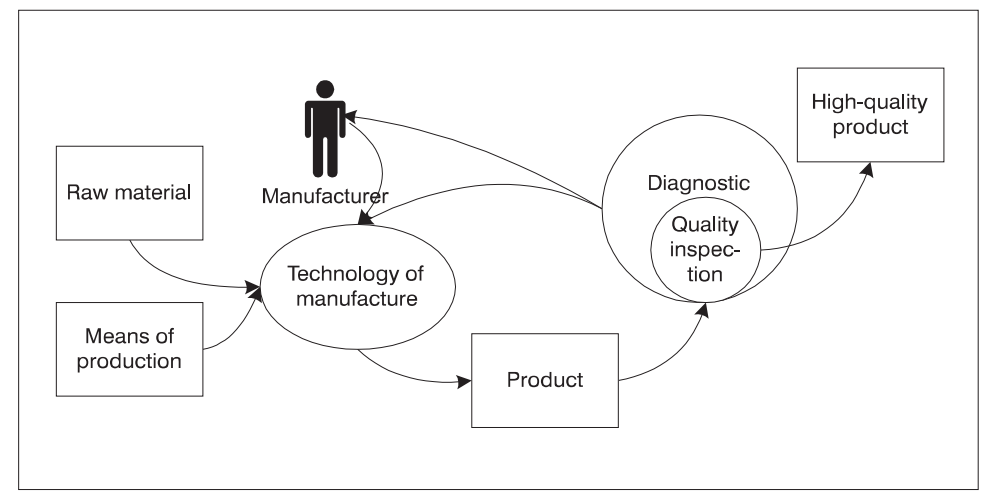

Figure 2. Inspection influence on the quality.

The outputs can be done in several ways:

by an expert whose decisions are based on personal experience (using expert knowledge),

following the norms and standards that embody, in the form of universal

(formal) knowledge, the generalized experience of many experts as well as results of theoretical research,

using both the universal and expert.

In the production systems the latter case is most frequent. Universal and expert knowledge can be mixed in different ways, although the expert knowledge is usually used as supplementary only. For example, the expert performs the final determination of quality category taking into account quantitatively undefined parameters such as the product trade appearance.

The sorting procedure is based on the following mathematical model:

$$
K=\min _{i=1,2, \ldots, N} K_{i}
$$

\footnotetext{
${ }^{2}$ Defective items are treated as one of quality categories.
} 
where $K$ is the quality category,

$K_{i}$ is the quality category according to parameter $i$,

$N$ is the number of a parameter.

In case the expert knowledge is used as supplementary knowledge, we can rewrite this model as follows:

$$
\begin{aligned}
& K=\min \left(K_{u}, K_{e}\right), \\
& K_{u}=\min _{j=1,2, \ldots, M} K_{j}, \\
& K_{e}=\min _{l=1,2, \ldots, L} K_{l}, \\
& M+L=N
\end{aligned}
$$

where $K$ is the quality category,

$K_{u}$ is the minimal quality category according to the norms and standards (universal knowledge),

$K_{e}$ is the minimal quality category according to experts (expert knowledge), $M$ is the number of the parameter evaluated using the universal knowledge,

$L$ is the number of the parameter evaluated using the expert knowledge,

$N$ is the number of all parameters.

According to this model, the universal knowledge $K_{u}$ and expert $K_{e}$ knowledge can be used separately. Therefore, we can split the inspection system in to two components and implement the component, which uses the universal knowledge only as a knowledge-based software system. Sometimes the expert knowledge $K_{e}$ may have an indirect influence on the results of this system, for example, in case an expert performs inspection of the product and indicates to the nature, number of defects and their mutual dislocation (e.g., in X-ray inspection of welded connections) of the system.

\section{KNOWLEDGE PATTERNS}

The quality inspection standards and norms contain quality requirements. It is universal (formal) knowledge of very specific kind. It is composed of constraints, rules, and definitions. As a result of the analysis of norms and standards used in quality inspection, we have identified the following basic knowledge patterns.

1. The constraints on the allowed magnitude of a parameter (characteristic).

2. Type constraints on inspected units.

3. Basic rules. The basic rules describe the quality inspection methods. In most cases, the rules describe how to compare norms and measured parameters of inspected unit.

4. The definitions. The definitions are typical declarative rules, which allow us to define the dependence between some characteristics or parameters, used in quality inspection.

5. Additional rules. Additional rules allow us to correct the behaviour of basic rules in some specific or exceptional cases. 
The knowledge pattern analysis enables us to conclude that the knowledge presented in the standards and norms is precise, unambiguous, complete, and trustworthy.

It should be noted that each quality category covers an area of some quality parameters fig. 3a) and these areas may overlap in various ways. The most interesting fact is that the product of a higher quality category, as a rule, meets the requirements of a lower quality. Nevertheless, it is determined as belonging to the higher category. In order to avoid ambiguities, categorization may be carried out based on areas (fig. 3b).

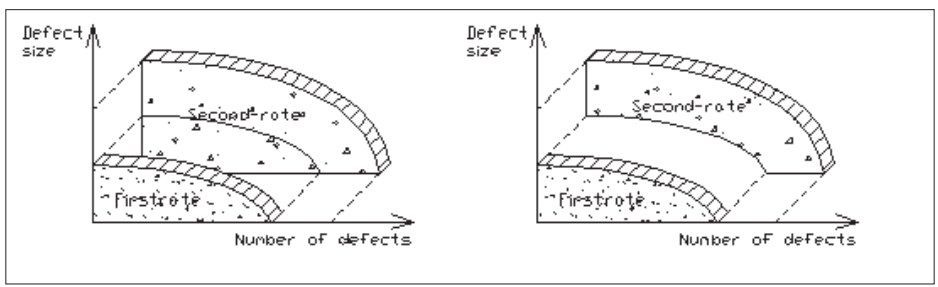

Figure 3. Overlapping of quality categories: a) in accordance with definitions of the standard, b) quality category areas used in practice.

Sometimes the product quality cannot be determined accurately basing on the existing parameters, and the quality inspection system may request additional data, in other words, sorting is performed in two stages (fig. 4).

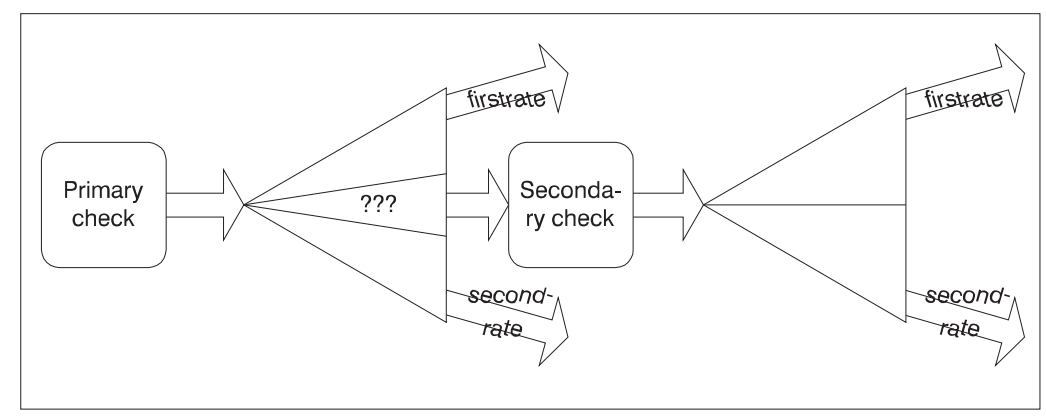

Figure 4. Two-stage process of quality category determination.

\section{SOFTWARE REQUIREMENTS AND ARCHITECTURE}

Some knowledge-based systems use embedded databases. Nevertheless, systems of such type are rather closed because the integration between data and knowledge is implemented on a low level [4]. Complicated data and knowledge interaction mechanisms often exclude a feasibility to integrate other products into systems because semantic relations between data and knowledge are con- 
cealed. In order to simplify the data and knowledge interaction, the software system should meet the following requirements:

- the application domain knowledge should be separated from the problem domain knowledge,

- the application domain knowledge should be represented using the relational data model and implemented as an external SQL server,

- the problem domain should be described by logical rules that refer to the database,

- knowledge base should be implemented as global entity (e.g. server) that can also be used in other applications.

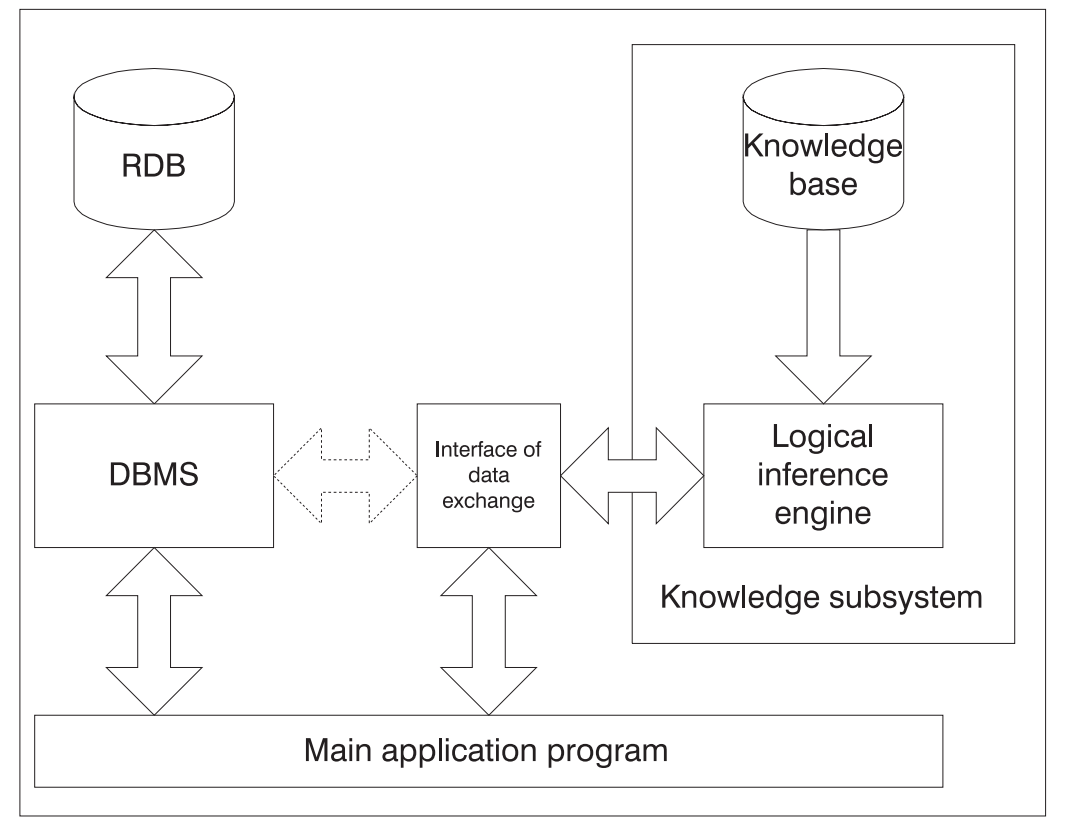

Figure 5. Conceptual architecture of the quality inspection system.

The software architecture that meets these requirements is presented in fig. 5. It is presented on conceptual level and may be implemented in many different ways [7]. Let us discuss this architecture more in detail. We propose to use three-level client server architecture. Three categories of components are used in this architecture: clients, servers and agents. Clients are components that instigate an interaction. They are active components that are responsible for handling control to other components. Servers are passive components that wait for another component to require their services. The flow of control is passed to the server by the component that sends the message and is recovered after execution of the service. Agents combine characteristics from both clients and servers. They dissociate clients from servers by introducing 
an indirection in the message propagation mechanism. It means that a client is able to communicate with a server that it does not know directly. In our case, agent act as a mediator that request the data about the inspected unit, queries knowledge server to decide about the quality of this unit, and informs the sorting server what must be done with this unit. The data server, knowledge server and sorting server are not visible for the client and it interacts only with the agent. The sorting server may be implemented in many different ways: it may be a manipulator, an operator, etc. We suggest that data server should be implemented as a SQL server and knowledge server should be implemented as a Prolog server. However, the proposed architecture allows to use other solutions, too. For example, the data server may be implemented also as telemeter device. It means that the agent can also request data from various sources, for example, from databases, sensors and keyboard.

\section{CONCLUSIONS}

We discussed issues of conceptual modelling of the product quality control process and the role of quality inspection in this process. We regard the inspection as the outcomes sorting and suppose that the sorting can be performed according to the prescriptive norms and standards that contain universal knowledge. The knowledge pattern analysis has been made and it is shown that all knowledge can be expressed in the Prolog-like logic formalism. The knowledge-based client-server architecture of the software system that acts as part of the quality inspection system has been proposed.

\section{REFERENCES}

[1] W.E. Deming. Out of the Crisis. Cambridge MA, MIT Press, 1989.

[2] Environmental Glossary. Environmental Health Centre, National Safety Council, 1025 Connecticut Avenue, NW, Suite 1200, Washington, DC $200361999^{3}$.

[3] D.A. Floyd. The Definition of Quality. Duane A. Floyd's Industrial Engineering and Quality Assurance Laboratory, $1999{ }^{4}$.

[4] K.A. Garnett, A.L. Reigel. Quality Assurance Computer System. Quality Assurance, 5 (3), 332-351, 1997.

[5] K. Ishikawa. What is total quality control? The Japanese way. Englewood Clifs, N.J.: Prentice-Hall, 1985.

[6] ISO 8402. Quality management and quality assurance vocabulary. Second edition. 199404-01.

[7] A. Ribikauskas, S. Maskeliūnas, O. Vasilecas. Investigation of architecture of the intellectualised product quality control system. Information technology \& control, 2 (11), Technologija, Kaunas, 1999, 43-56.

[8] T. Russel. Background to ISO $9000^{5}$.

\footnotetext{
${ }^{3}$ http://skinnypuppy.webfirst.com/nsc/ehc/glossary.htm

${ }^{4}$ http:// geocities. com/CapeCanaveral/Lab/9183/qualfrm2.html

${ }^{5}$ http://www.iso-9000.co.uk/9000qfa1.html
} 
[9] M. Shigeru. Company-wide total quality control. White Plains, N.Y., 1988.

[10] R. Siamin, A. H. Hj. Ghazali. Quality Corner. UUM Library Quality Manager. UUM Library, $1998^{6}$.

\title{
KOKYBĖS KONTROLĖS PROCESU KONCEPTUALŪS
} MODELIAI

\author{
A. RIBIKAUSKAS, O. VASILECAS, A. C̆APLINSKAS
}

Straipsnyje aptariamas produktų kokybès kontrolès procesų konceptualus modeliavimas. Ypatingas dèmesys atkreipiamas ż kokybès kontrolę. S̆is procesas gali būti nagrinëjamas kaip produktų rūšiavimo variantas, kurio tikslas - nustatyti produktų kokybès kategoriją. Tariama, kad rūšiavimas gali būti atliekamas pagal aprašomas normas ir standartus. Straipsnyje nagrinëjamos specifinès žinių savybès, aprašomos pagal šias normas ir standartus, aptariama, kaip aprašyti žinias logine programa ir pasiūlyti žinojimu paremtos architektūros programinès i̇rangos sistemą, kuri veikia kaip kokybès sistemos dalis ir igyvendina produktu kokybės kontrolès procesą.

\footnotetext{
${ }^{6}$ http://www.lib.uum.edu.my/ref/quality/
} 